\title{
A comparison of dung beetle assemblage structure (Coleoptera: Scarabaeidae: Scarabaeinae) between an Atlantic forest fragment and adjacent abandoned pasture in Paraná, Brazil
}

\author{
José Lopes', 4; Vanesca Korasaki²; Lizandra L. Catelli3; \\ Viviani V. M. Marçal ${ }^{3} \&$ Maria Paula B. P. Nunes ${ }^{3}$
}

\author{
${ }^{1}$ Departamento de Biologia Animal e Vegetal, Universidade Estadual de Londrina. Caixa Postal 6001, Campus Universitário, \\ 86055-900 Londrina, Paraná, Brasil. E-mail: jea@uel.br \\ 2 Universidade Federal de Lavras. Caixa Postal 3037, Campus Universitário, 37200-000 Lavras, MG, Brasil. \\ E-mail: korasaki@hotmail.com \\ ${ }^{3}$ Centro Universitário Filadélfia. Avenida Juscelino Kubitschek 1626, Caixa Postal 196, 86020-000 Londrina, PR, Brazil. \\ ${ }^{4}$ Corresponding author.
}

\begin{abstract}
The study was conducted at the Mata dos Godoy State Park in Londrina, state of Paraná, Brazil. Baited pitfall traps were installed in the forest, in adjacent abandoned pasture land, and on the borders between these two environments. Every two weeks, from June 1999 to May 2000, the traps were placed for 24 hours and the material was collected every 12 hours. The 4687 specimens of Scarabaeinae collected belong to 13 genera and 27 species. The most frequent species were Onthophagus catharinensis (Paulian, 1936) (22.1\%), Onthophagus hirculus (Mannerhein, 1829) (20.1\%), Dichotomius mormon (Ljungh, 1799) (13.1\%), Sulcophanaeus menelas (Laporte, 1840) (12.8\%), and Eurystemus parallelus (Dalman, 1824) (10.6\%). The other species collected amounted to less than $4.7 \%$. The difference in numbers of specimens collected in the three environments was not significant $\left(\mathrm{K}_{(2.72)}=0.63, \mathrm{p}=0.729\right)$. The distribution patterns of species composition for the different environments (ANOSIM R =0.29, $p<0.01$ ) and activity periods (ANOSIM R $=0.18, p<0.01$ ) were different. Sulcophanaeus menelas, Canthidium aff. trinodosum, O. hirculus, and E. parallelus were the most abundant species, being predominantly diurnal; the first three species were more active on abandoned pasture. Most of the Dichothomius assifer (Eschscholtz, 1822) and D. mormon specimens were captured at night. The latter species was the most abundant in edges, whereas D. assifer, Scybalochantum aff. zischkai, and O. catharinensis can be considered bioindicators because they were either exclusively or highly predominant in the best preserved areas. A larger number of individuals was observed from December 1999 through March 2000, which is the time of the year when adults of Scarabaeinae normally emerge and fly, in the studied region. The highest diversity (88.89\%) was observed in February.
\end{abstract}

KEY WORDS. coprophagous beetle; ecological indicator; forest fragment; pitfall; Scarabaeidae.

The presence of native forest fragments significantly improves landscape diversity and increases the survival probability of the native biota in Neotropical region where deforestation occurs (TURNer \& CORLETT 1966). The conservation of biodiversity is an important challenge considering the high level of anthropic disturbance in natural ecosystems and their resulting fragmentation (Viana \& Pinheiro 1998).

The Atlantic Forest in the state of Paraná is one of the most important biodiversity "hotspots" of the world and also one of the most threatened ecosystems (RANTA et al. 1998, MYers et al. 2000). The State of Paraná has suffered a significant loss of its native vegetation cover and currently has only a few fragments of its remnant forest, mostly surrounded by crop or pasture land (MedRi \& Lopes 2001a). Only 2 to $4 \%$ of the original forest in Northern Paraná remains (SOARES \& MEdRI 2002).
Insects, particularly dung beetles of the subfamily Scarabaeinae (Coleoptera, Scarabaeidae), play an important ecological role in several biological processes occurring in terrestrial environments (Nichols et al. 2008), such as the control of some vertebrate parasites (BorNemissza 1970, KLEIN 1989, Flechtmann et al. 1995), soil bioperturbation and pollination (Küchmeister et al. 1998, SAKaI \& Inoue 1999), seed dispersal (Feer 1999, ANDRESEN 2002), and nutrient cycling (GuerRa et al. 2007).

The scarabaeines contribute to nutrient cycling because most of these beetles are dependent on soil for shelter and nidification (HALFFTER \& MATtHEws 1966) and due to their detritivorous feeding habits; they use decomposing feces, carcasses, and fruits as food resources (VAZ-DE-MelLo 1999). Therefore, the optimal method to monitor insect abundance in this family consists of pitfall traps baited with decomposing dung, carcasses, or fruits. 
The traps are installed in holes dug in the soil, the trap top rim being leveled with soil surface (Favila \& HaLfFTer 1997).

Scarabaeinae beetles are sensitive indicators of environmental quality (Favila \& HalfFter 1997, Davis et al. 2001, SPECTOR 2006) and respond negatively to disturbances such as forest clearing and cutting (VuLinec 2002), decreases in mammal populations - which lead to lower availability of dung in the soil (ANDRESEN 2007), and forest fragmentation (Klein 1989). In this context, our study surveyed the Scarabaeinae species attracted to pig dung bait; compared the diversity, the abundance and the quality of Scarabaeinae fauna in different ecotopes; analyzed the occurrence and density of populations during one year; and partitioned species according to their nocturnal or diurnal activities. These results allow us to compare the population and species composition in this area to other regions and make some recommendations for conservation.

\section{MATERIAL AND METHODS}

The study was conducted at the Mata dos Godoy State Park, located about $15 \mathrm{~km}\left(23^{\circ} 27^{\prime} \mathrm{S}\right.$ and $\left.51^{\circ} 15^{\prime \prime} \mathrm{W}\right)$ from downtown Londrina, state of Paraná, with an altitude between 610$650 \mathrm{~m}$. The Park occupies 680 ha, of which 580 ha are still covered by a continuous, well-preserved forest (CHAGAS E SILVA $\&$ SOARES-SILVA 2000). The remaining 100 ha contain reforestation areas, a secondary forest, and a deforested area used as cattle pasture twenty years ago; at the time of the study, the area was completely covered by Panicum maximum Jacq. and other herbaceous plants, all about two meters tall.

According to the Köppen classification, the region has a Cfa, subtropical and humid climate, with rain throughout the year and occasional droughts in winter (MENDONÇA 2000). According to the data provided by IAPAR (Instituto Agronômico do Paraná), the mean annual temperature is $24.1^{\circ} \mathrm{C}$ and the mean annual rainfall, $1686 \mathrm{~mm}$. The soil is Eutrophic Red Latosol.

The pitfall traps were placed inside the forest and along forest edges and, for comparison, were placed also in the adjacent abandoned pasture. The adjacent area is approximately $500 \mathrm{~m}$ from the eastern edge of the forest fragment. The traps consisted of $23 \mathrm{~cm}$ deep plastic containers with $9.5 \mathrm{~cm}$ diameter. A small flask containing bait (50 g of pig dung) was covered with a perforated lid to exude the odor of decomposing feces, and placed inside the container, next to its upper rim. We added $200 \mathrm{ml}$ of water with detergent to each trap. A wooden device (as described by MEDRI \& Lopes 2001b) was placed around the opening to prevent soil from falling into the container.

Samples were collected from June 1999 through May 2000. We installed the traps twice a month, every two weeks. Traps remained in the field for 24 hours and the biological material was collected at 6:00 am and 6:00 pm, resulting in both diurnal and nocturnal collections. Two traps were installed inside the forest, two on the forest edges and two on the adjacent pastureland. The traps were placed with their upper rim leveled with the soil surface, $50 \mathrm{~m}$ apart from each other in each of the three areas. The Scarabaeinae beetles were sorted according to morphological traits, mounted on entomological pins, and identified by Fernando Zagury Vaz-de-Melo (Universidade de Mato Grosso, Instituto de Biociência, Cuiabá, Mato Grosso).

For the similarity analysis of species composition in the different environments and the determination of the activity period of the sampled scarabaeines, we used NMDS (nonmetric multidimensional scaling) based on the Bray-Curtis Index (Clarke \& WARWICK 2001), using the program software PRIMER v.5 (Clarke \& Gorley 2001). The data were transformed into square roots to reduce the influence of rare and dominant species and standardized to remove the sample size effect.

Community characteristics were observed after defining categories of species abundance and population fluctuation during the 12 months of data collection. We assessed diversity with the Shannon index (MagurRan 1998), and richness estimates using the program EstimateS 7.5 (Colwell 2005). We plotted the rarefaction curves using Sobs (Mao Tau). The KruskalWallis test was used to determined abundance differences among the three environments and for the activity periods, whereas the program Statistica for Windows v. 6 (STATSOFT 2001) was used for the activity periods. We used the non-parametric Spearman correlation test to relate precipitation and temperature to the number of captured individuals.

The specimens were deposited in the collections of the Zoology Department at UEL (Universidade Estadual de Londrina, Paraná, Brazil) and the Entomology Section of the Zoology Collection at UFMT (Universidade Federal de Mato Grosso, Cuiabá, Mato Grosso, Brazil).

\section{RESULTS AND DISCUSSION}

The 4687 specimens of Scarabaeinae collected belong to 13 genera and 27 species (Tab. I). The most abundant species were Onthophagus catharinensis Paulian, 1936 (22.1\%), Onthophagus hirculus Mannerhein, 1829 (20.1\%), Dichotomius mormon (Ljungh, 1799) (13.1\%), Sulcophanaeus menelas (Laporte, 1840) (12.8\%), and Eurysternus parallelus Dalman, 1824 (10.6\%). Each of the remaining species represented less than $4.7 \%$ of all the species collected. Deltochilum Eschscholtz, 1822 showed the highest diversity, with five species. The genus has ca. 80 described species occurring primarily in tropical forests, and having necrophagous or copro-necrophagous habits. A taxonomic review is needed due to the large number of species recently found, particularly in Neotropical forests and savannahs (VAZ-DE-MeLLo 1999).

The Shannon index was lower in the deforested area covered with P. maximum (Tab. I). SCHeFfLer (2005) found the same value for the Shannon index in pasture land when studying forest areas after selective cutting, clearing, and pasture areas.

The number of individuals collected in the three environments did not differ according to the Kruskal-Wallis test ( $p$ 
Table I. Scarabaeinae collected in pitfall traps baited with pig dung in forest, forest edges, and adjacent pasture at the Mata dos Godoy State Park, Londrina, Paraná, from June 1999 to May 2000.

\begin{tabular}{|c|c|c|c|c|c|c|c|c|}
\hline \multirow{2}{*}{ Tribe/species } & \multirow{2}{*}{ Period of Activity } & \multicolumn{2}{|c|}{ Forest } & \multicolumn{2}{|c|}{ Forest edges } & \multicolumn{2}{|c|}{ Adjacent Pasture } & \multirow{2}{*}{ Total } \\
\hline & & Day & Night & Day & Night & Day & Night & \\
\hline \multicolumn{9}{|l|}{ Phanaeini } \\
\hline Coprophanaeus jasius (Olivier, 1789) & - & 0 & 0 & 0 & 1 & 0 & 0 & 1 \\
\hline Diabroctis mimas Linnaeus, 1767 & - & 0 & 0 & 1 & 0 & 5 & 0 & 6 \\
\hline Sulcophanaeus menelas (Laporte, 1840) & Diurnal & 0 & 5 & 0 & 2 & 590 & 4 & 601 \\
\hline \multicolumn{9}{|l|}{ Dichotomiini } \\
\hline Canthidium cavifrons Balthasar, 1939 & Diurnal & 6 & 0 & 2 & 1 & 4 & 0 & 13 \\
\hline Canthidium aff. trinodosum & Diurnal & 39 & 24 & 30 & 18 & 103 & 4 & 218 \\
\hline Dichotomius assifer (Eschscholtz, 1822) & Nocturnal & 2 & 54 & 1 & 52 & 0 & 0 & 109 \\
\hline Dichotomius carbonarius Mannerheim, 1829 & Nocturnal & 0 & 4 & 0 & 6 & 0 & 0 & 10 \\
\hline Dichotomius depressicollis Harold, 1867 & Nocturnal & 0 & 6 & 0 & 4 & 0 & 0 & 10 \\
\hline Dichotomius mormon (Ljungh, 1799) & Nocturnal & 0 & 136 & 2 & 474 & 0 & 3 & 615 \\
\hline Dichotomius nisus Olivier, 1789 & & 0 & 0 & 0 & 2 & 0 & 0 & 2 \\
\hline Ontherus azteca Harold, 1869 & Nocturnal & 0 & 3 & 0 & 2 & 0 & 0 & 5 \\
\hline Ontherus sulcator (Fabricius, 1775) & Nocturnal & 0 & 6 & 1 & 9 & 0 & 10 & 26 \\
\hline Uroxys sp. & Nocturnal & 1 & 1 & 0 & 8 & 0 & 27 & 37 \\
\hline \multicolumn{9}{|l|}{ Canthonini } \\
\hline Canthon chalybaeus Blanchard, 1843 & Diurnal & 9 & 2 & 26 & 2 & 35 & 2 & 76 \\
\hline Canthon aff. rutilans & - & 0 & 0 & 19 & 1 & 1 & 0 & 21 \\
\hline Canthon sp. & Diurnal & 4 & 0 & 5 & 2 & 2 & 0 & 13 \\
\hline Deltochilum furcatum Castelnau, 1840 & Nocturnal & 0 & 8 & 0 & 1 & 0 & 0 & 9 \\
\hline Deltochilum valgum Burmeister, 1873 & - & 0 & 2 & 0 & 0 & 0 & 0 & 2 \\
\hline Paracanthon pereirai d'Andreatta \& Martinez, 1957 & Diunal/Noctumal & 6 & 11 & 0 & 1 & 1 & 0 & 19 \\
\hline Scybalocanthon aff. zischkai & Diunal/Nocturnal & 32 & 13 & 1 & 9 & 0 & 0 & 55 \\
\hline \multicolumn{9}{|l|}{ Oniticellini } \\
\hline Eurystemus hirtellus Dalman, 1824 & - & 0 & 0 & 1 & 0 & 0 & 0 & 1 \\
\hline Eurystemus parallelus (Dalman, 1824) & Diurnal & 178 & 13 & 267 & 14 & 25 & 0 & 497 \\
\hline Eurystemus aff. caribaeus & Diunal/Nocturnal & 4 & 47 & 3 & 70 & 87 & 2 & 213 \\
\hline \multicolumn{9}{|l|}{ Onthophagini } \\
\hline Onthophagus catharinensis Paulian, 1936 & Diunal/Nocturnal & 210 & 481 & 141 & 199 & 5 & 1 & 1037 \\
\hline Onthophagus hirculus (Mannerhein, 1829) & Diurnal & 40 & 62 & 23 & 12 & 802 & 3 & 942 \\
\hline Onthophagus aff. buculus & Diunal/Nocturnal & 3 & 21 & 13 & 20 & 15 & 0 & 72 \\
\hline Onthophagus aff. ranunculus & Diurnal & 0 & 0 & 1 & 0 & 76 & 0 & 77 \\
\hline Total of specimens & & 534 & 899 & 537 & 910 & 1751 & 56 & 4687 \\
\hline Total of species & & 13 & 19 & 17 & 23 & 14 & 9 & \\
\hline $\mathrm{H}^{\prime}$ & & & 1.86 & & 1.95 & & 1.52 & \\
\hline
\end{tabular}


$=0.729$ ). Analyzing the observed abundances for each species in the three environments, Scybalocanthon aff. zischkai, Paracanthon pereirai d'Andreatta \& Martinez, 1957, and $O$. catharinensis occurred more often in the forested area and $O$. catharinensis occurred less in forest edges and had the smallest frequency in abandoned pasture land. Dichotomius assifer (Eschscholtz, 1822), D. mormon, and E. parallelus were more abundant in the forest and in the forest edges as compared with abandoned pasture. Our results for Dichotomius Hope, 1838 do not agree with those reported by Vulinec (2002) for the Amazon Basin, where the species abundance of this genus increased with higher levels of habitat disturbance, including the most disturbed among the habitats studied, whereas all other scarabaeines were scarce. ANDRESEN (2005) and SiLVA et al. (2007b) state that Dichotomius species are often associated with habitat changes and resource abundance. The lack of specific food resources in abandoned pasture areas may have been the limiting factor for colonization of this group. Canthon aff. rutilans Laporte, 1840 was more abundant in the forest edges, whereas S. menelas, O. hirculus, and Onthophagus aff. ranunculus were more abundant in pasture areas. Canthon aff. rutilans and $O$. aff. ranunculus occurred only in cleared areas, suggesting that they can be opportunistic species as well as indicators of areas under substantial anthropic disturbance.

More individuals were collected in abandoned pasture during the day as compared to the night period $\left(\mathrm{K}_{(1.48)}=8.04\right.$, $\mathrm{p}<0.05)$. Onthophagus hirculus and $S$. menelas together amounted to $79.45 \%$ of the total abundance in abandoned pasture during the day. Sulcophanaeus menelas, Canthidium cavifrons Balthasar, 1939, Canthidium aff. trinodosum (Bohemann, 1858), Canthon chalybaeus Blanchard, 1843, Canthon sp., E. parallelus, O. hirculus, and $O$. aff. ranunculus were active during the day, whereas $D$. assifer, Dichotomius carbonarius Mannerheim, 1829, Dichotomius depressicollis Harold, 1867, D. mormon, Ontherus azteca Harold, 1869, Ontherus sulcator (Fabricius, 1775), and D. furcatum were active at night. HERNÁNDEZ (2007) studied the activity pattern of $O$. hirculus and classified the species as having diurnal habits as observed in this study. HALFFTer et al. (1992) reported that diurnal species were predominant in disturbed environments. AIDAR et al. (2000) found that most individuals had crepuscular/nocturnal activities in pasture, and that activity patterns can vary with habitat changes.

Five species had diurnal and nocturnal habits, among them Eurysternus aff. caribaeus and Onthophagus aff. bucculus. Although both species were always active, they were more abundant during the day in the forest and in the pasture, respectively (Tab. I).

MEDRI \& Lopes (2001a) found 35 species of Scarabaeinae belonging to 12 genera when collecting beetles on the same forest fragment used in this study and adjacent pasture where there were cattle and horses. The larger number of species may be due to the presence of cattle and the use of baits prepared with decomposing meat. As reported by AlmEIDA \& LouzADA
(2009), bait type affects both the abundance of individuals and the species captured. Louzada \& Lopes (1997) found 21 species belonging to 11 genera in a fragment of the Atlantic Forest in Viçosa, State of Minas Gerais. Similar to our results, SCHIffLer et al. (2003) collected 23 species belonging to 13 genera during a study in a cocoa-growing area associated with the Atlantic Forest (Cocoa-Cabruca $=$ ecological system of cultivation agroforestry) and in areas of alluvial forest, forest restinga, pasture, and shrubby 'restinga'.

Similarity was low among the three environments, varying from $30.2 \%$ (forest edges and forest) to $13.6 \%$ (pasture and forest). The distribution pattern of species composition was different for each environment (Fig. 1, ANOSIM R =0.29,
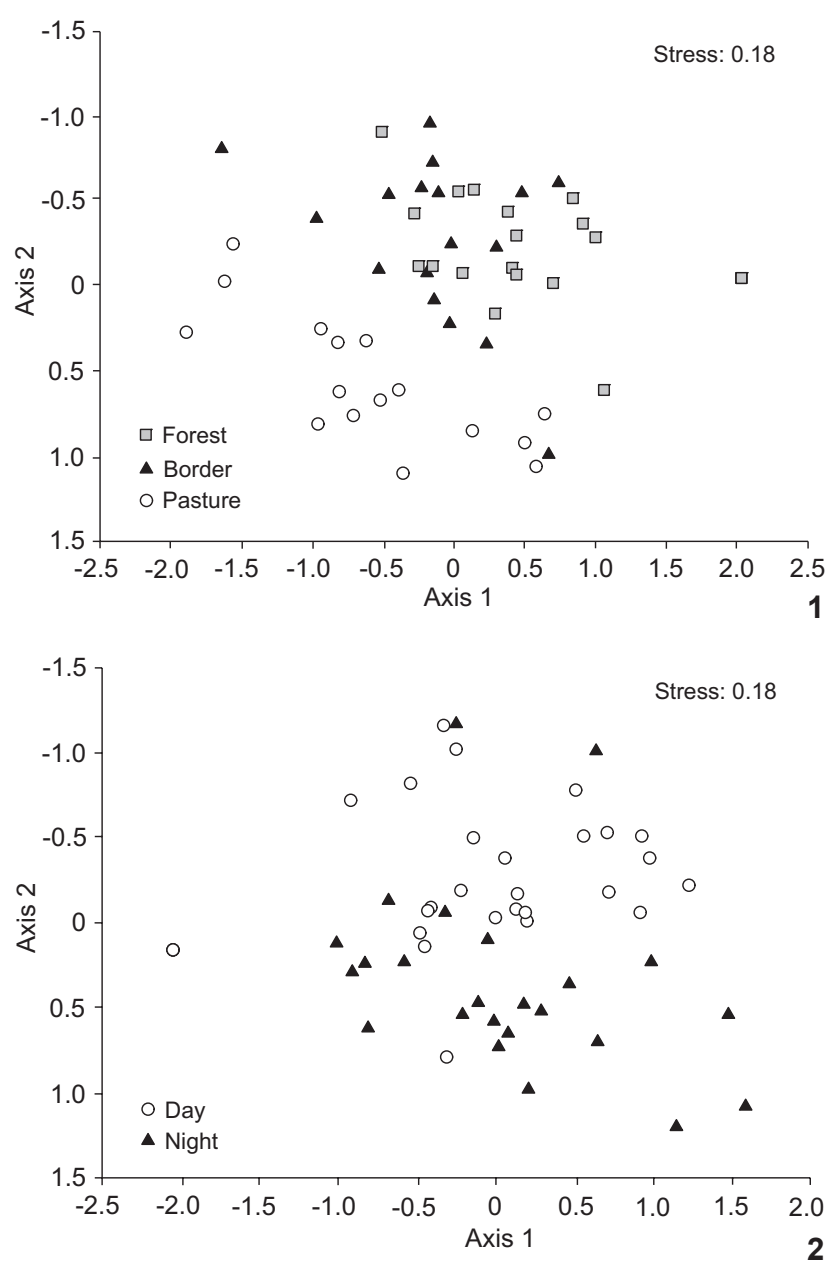

Figures 1-2. Pattern of distribution of sample dots according to species composition, following the grouping defined by NMDS based on the Bray-Curtys index, in forest, edges and adjacent pasture, at the Mata dos Godoy State Park, Londrina, from June 1999 to May 2000: (1) ecotope; (2) period of activity. Pitfall traps which collected no individuals were not included in the analysis. 
$\mathrm{p}<0.01$ ) and activity period (Fig. 2, ANOSIM $\mathrm{R}=0.18$, $\mathrm{p}<0.01)$. The dissimilarity mean between day and night was $79.7 \%$, and six species together were responsible for approximately $60 \%$ of the dissimilarity (O. catharinensis, $C$. aff. trinodosum, E. parallelus, O. hirculus, P. pereirai and D. mormon). Using the same analysis, GARDNER et al. (2008) were able to discriminate habitats by studying abundance and biomass in areas of primary forest, of eucalyptus reforestation areas, and also in areas where the native Amazon Basin vegetation was being reestablished.

A seasonal distribution of individuals was observed, with more specimens seen between December and March, the period when these beetles fly in large numbers in the Northern part of Paraná State. Fewer individuals were collected during the winter (June to August), when the weather is drier and cooler. Morelli et al. (1996) studied the life cycle of S. menelas in laboratory and found that adults live an average of 291 days, between March and January. Beetles were collected from October through May, with a peak in April. Canthidium aff. trinodosum was collected throughout the year except in June. Rainfall did not affect the collected specimens number (Spearman $\mathrm{R}^{2}=0.00, \mathrm{p}>0.05$ ), but when the dung beetles collected at night and during the day were analyzed separately, a significant positive correlation between abundance the dung beetles collected during the night and precipitation was observed (Spearman $\mathrm{R}^{2}=0.52, \mathrm{p}<0.05$ ) (Fig. 3). In turn, temperature positively affected the beetles collected number in both periods (Spearman $\mathrm{R}^{2}=0.46, \mathrm{p}<0.05 ; \mathrm{R}^{2}=0.33, \mathrm{p}<0.05$ ) (Fig. 4). Amézquita et al. (1999) suggest that temperature and soil humidity must be taken into account in population or community studies because they affect the activity of Scarabaeinae beetles.

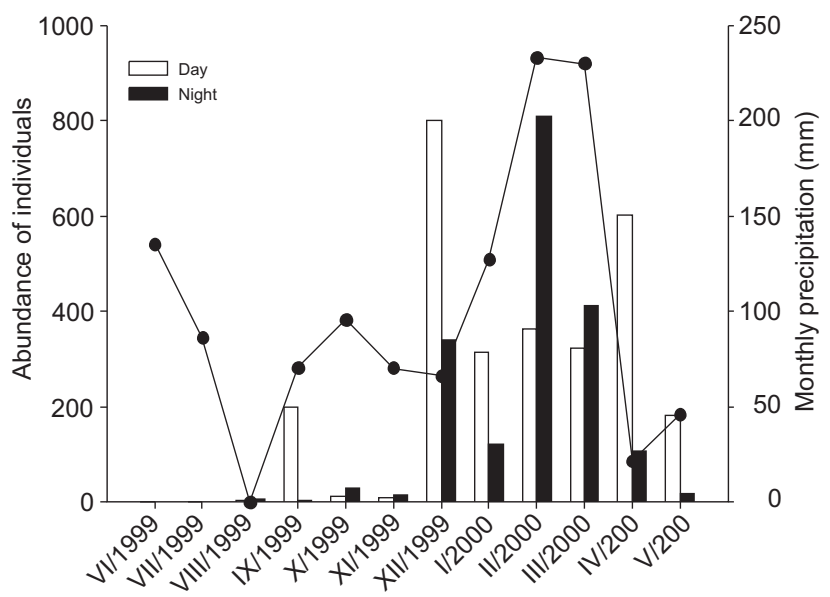

Figure 3. Correlation between monthly precipitation $(\mathrm{mm})$ and abundance of Scarabaeinae collected in forest, edges, and adjacent pasture at the Mata dos Godoy State Park, Londrina, from June 1999 to May 2000.

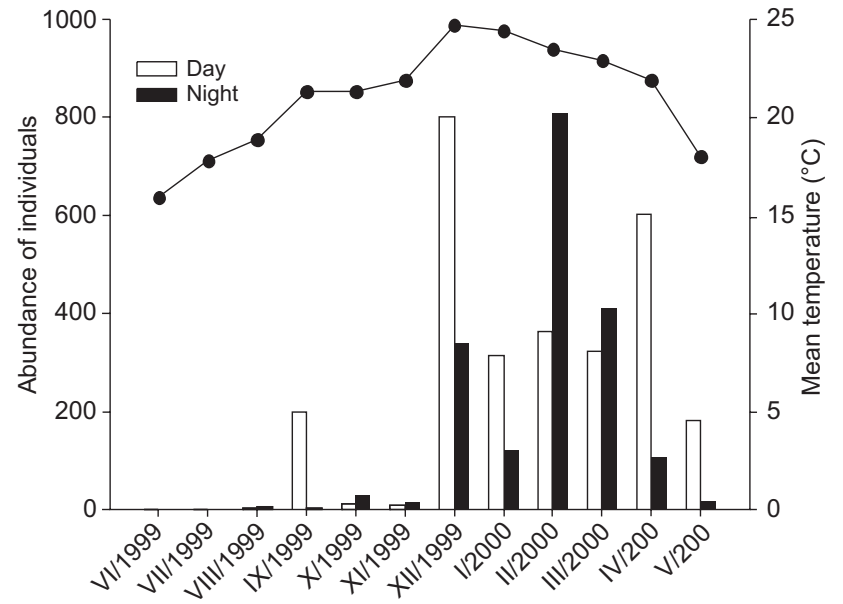

Figure 4. Correlation between mean temperature $\left({ }^{\circ} \mathrm{C}\right)$ and abundance of Scarabaeinae collected in forest, forest edges and adjacent pasture at the Mata dos Godoy State Park, Londrina, from June 1999 to May 2000.

The species accumulation curve did not reach an asymptote, the pasture land and the forest edges had a higher and lower tendency to asymptote during the night (Fig. 5), respectively. The non-stabilization of the species accumulation curve can be a result of the small number of traps placed in the study area. We found only two singleton species and two doubleton species, which can be considered 'rare' in the region. These species could be more easily captured if more traps were installed. Similar studies have found several singleton and doubleton species, thus increasing the knowledge of local diversity (Medri \& Lopes 2001a, Durães et al. 2005, Lopes et al. 2006, SiLva et al. 2007a, b, 2008, Costa et al. 2009). When we consider the number of species per collected individuals, the pasture land presents very low diurnal and nocturnal abundances, whereas the border and the forest areas have higher diversity at night (Fig. 6). The higher nocturnal diversity can be explained by some species engaging in activities during the coolest hours to avoid water loss through evaporation (ENDREs et al. 2005). It can also be due to the survival strategies used by the species to avoid predators with diurnal habits, particularly insectivore birds.

Most species in our study areas were represented by few individuals. For HalfFter (1991), species distribution in tropical forests is characterized by a few, very abundant species and many species with very few individuals. The same pattern can also be found in several studies - see Medri \& Lopes (2001a), Estrada \& Coates-Estrada (2002), Ronqui \& Lopes (2006), and GARDNER et al. (2008).

In conclusion, the community of Scarabaeinae beetles in the Mata dos Godoy State Park is highly affected by temperature throughout the year and by rainfall for nocturnal beetles, indicating that summer months are the best time for 

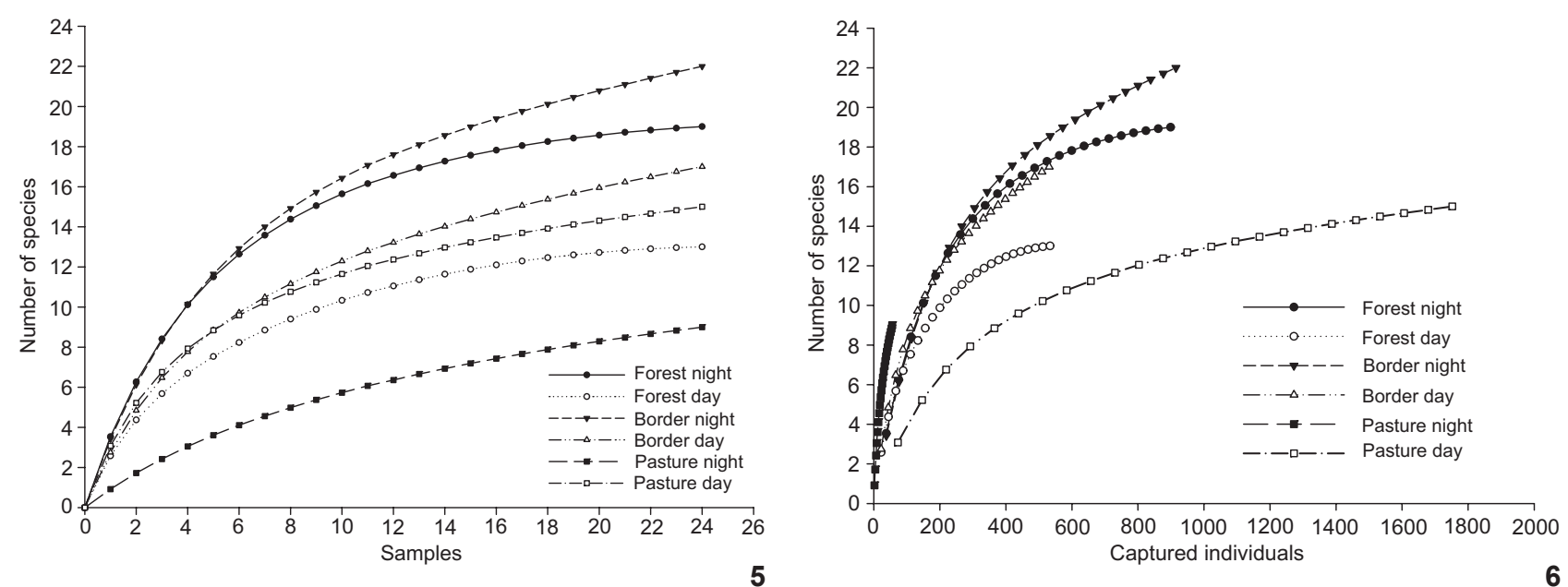

Figures 5-6. Species accumulation curve (Mao Tau) of Scarabaeinae (5) per number of samples in forest and (6) per individuals collected in forest, forest edges and adjacent pasture in diurnal and nocturnal periods, at the Mata dos Godoy State Park, Londrina, from June 1999 to May 2000.

collection of these beetles in this region. The community structure patterns found are very similar to those reported in other studies conducted in the Neotropical region.

\section{ACKNOWLEDGEMENT}

We thank Fernando Z. Vaz-de-Mello for the identification of the Scarabaeinae species collected in this research.

\section{LITERATURE CITED}

Aidar, T.; W.W. Koller; S.R. Rodrigues; A.M. CorrêA; J.C.C. DA Silva; O.S. Balta; J.M. Oliveira; V.L. Oliveira. 2000. Besouros coprófagos (Coleoptera: Scarabaeidae) coletados em Aquidauana, MS, Brasil. Anais da Sociedade Entomológica do Brasil 29: 817-820.

Almeida, S.P. \& J.N.C. LouZADA. 2009. Estrutura da comunidade de Scarabaeinae (Scarabaeidae: Coleoptera) em fitofisionomias do Cerrado e sua importância para a conservação. Neotropical Entomology 38: 32-43.

Amézquita, S.J.M; A. Forsyth; A.T. Lopera \& A.M. Camacho. 1999. Comparacion de la composicion y riqueza de espécies de escarabajos coprofagos (Coleoptera: Scarabaeidae) en remanentes de bosque de la Orinoquia Colombiana. Acta Zoologica Mexicana 76: 113-126.

Andresen, E. 2002. Dung beetles in a Central Amazonian rainforest and their ecological role as secondary seed dispersers. Ecological Entomology 27: 257-270.

Andresen, E. 2005. Effects of season and vegetation type on community organization of dung beetles in a tropical dry forest. Biotropica 37: 291-300.

ANDRESEN, E. 2007. Possible indirect effects of mammal hunting on dung beetle assemblages in Panama. Biotropica 39: 141-146.
BorNEMISSZA, G.F. 1970. Insectary studies on the control of dung breeding flies by the activity of the dung beetle, Onhtophagus gazella F. (Coleoptera: Scarabaeidae). Journal of the Australian Entomological Society 9: 31-41.

Chagas E Silva, F. DAS \& L.H. Soares-Silva. 2000. Arboreal flora of the Godoy Forest State Park, Londrina, PR. Brazil. Edinburgh Journal of Botany 57: 107-120.

Clarke, K.R. \& R.M. WARWick. 2001. Change in marine communities: an approach to statistical analysis and interpretation. Plymouth, PRIMER-E Ltd, Plymouth Marine Laboratory, $2^{\text {nd }}$ ed., $172 p$.

Clarke, K.R. \& R.N. GoRley. 2001. Software PRIMER, v. 5. Plymouth, PRIMER-E.

Colwell, R.K. 2005. EstimateS: statistical estimation of species richness and shared species from samples, v. 7.5.0. Available online at: http://viceroy.eeb.uconn.edu/estimates [Accessed: 02.IX.2010].

Costa, C.M.Q.; F.A. Silva; A.I. Farias \& R.C. Moura. 2009. Diversity of Scarabaeinae (Coleoptera, Scarabaeidae) collected with flight intercept trap in the Charles Darwin Ecologic Refuge, Igarassu-PE, Brazil. Revista Brasileira de Entomologia 53: 88-94

Davis, A.J.; J.D. Holloway; H. HujjBregts; J. KrikKen; A.H. Kirk-Spriggs \& L. SutTon. 2001. Dung beetles as indicators of change in the forest of Borneo. Journal of Applied Ecology 38: 593616.

Durães, R.; W.P. Martins \& F.Z. VaZ-De-Mello. 2005. Dung beetle (Coleoptera: Scarabaeidae) assemblages across a natural forest-cerrado ecotone in Minas Gerais, Brazil. Neotropical Entomology 34: 721-731.

Endres, A.A.; M.I.M. Hernández; A.J. Creão-Duarte. 2005. Considerações sobre Coprophanaeus ensifer (Germar) (Coleoptera, 
Scarabaeidae) em um remanescente de Mata Atlântica no estado da Paraíba, Brasil. Revista Brasileira de Entomologia 49: 427-429.

Estrada, A. \& R. Coates-Estrada. 2002. Dung beetles in continuous forest, forest fragments and in an agricultural mosaic habitat island at Los Tuxtlas, Mexico. Biodiversity and Conservation 11: 1903-1918.

Favila, M.E. \& G. Halffter. 1997. The use of indicator groups for measuring biodiversity as related to community structure and function. Acta Zoológica Mexicana 72: 1-25.

FeEr, F. 1999. Effects of dung beetles (Scarabaeidae) on seeds dispersed by monkeys (Alouatta seniculus) in the French Guianan rain forest. Journal of Tropical Ecology 15: 129142.

Flechtmann, C.A.H.; S.R. Rodrigues \& H.T.Z. Couto. 1995. Controle biológicoda msoca-dos-chifres (Haematobia irritans irritans) em Selvíria, Mato Grosso do Sul - 4: comparação entre métodos de coleta de besouros coprófagos (Scarabaeidae). Revista Brasileira de Entomologia 39: 259-276.

Gardner, T.A.; M.I.M. Hernández; J. Barlow \& C.A. Peres. 2008. Understanding the biodiversity consequences of habitat change: the value of secondary and plantation forests for neotropical dung beetles. Journal of Applied Ecology 45: 883-893

Guerra, M.B.B.; C.E.G.R. Schaefer \& L. Sousa-Souto. 2007. Características químicas do lixo de formigueiros de Atta sexdens rubropilosa (Hymenoptera: Formicidae) mantidos com diferentes substratos. Revista Brasileira de Ciências do Solo 31: 1185-1189.

HALFFTER, G. 1991. Historical and ecological factors determining the geographical distribuition of beetles (Coleoptera: Scarabaeidae: Scarabaeinae). Folia Entomológica Mexicana 82: 195-238.

Halffter, G. \& E.G. Matthews. 1966. The history of dung beetles of the subfamily Scarabaeinae (Coleoptera: Scarabaeidae). Folia Entomológica Mexicana 12/14: 1-312.

Halffter, G.; M.E. Favila \& V. HalfFter. 1992. A comparative study of the structure of the scarab guild in Mexican tropical rain forests and derived ecosystems. Folia Entomológica Mexicana 84: 131-156.

Hernández, M.I.M. 2007. Besouros escarabeíneos (Coleoptera: Scarabaeidae) da caating Paraibana, Brasil. Oecologia Brasileira 11: 356-364.

KLEIN, B.C. 1989. Effects of forest fragmentation on dung and carrion beetle communities in Central Amazonia. Ecology 70: $1715-1725$.

Küchmeister, H.; A.C. Webber; I. Silberbauer-Gottsberger \& G. Gottsberger.1998. A polinização e sua relação com a termogênese em espécies de Arecaceae e Annonaceae da Amazônia Central. Acta Amazônica 28: 217-245.

LOUZADA, J.N.C. \& F.S. Lopes. 1997. A Comunidade de Scarabaeidae Copro-Necrófagos (Coleoptera) de um Fragmento de Mata Atlântica. Revista Brasileira de Entomologia 41: 117-121.
Lopes, P.P.; J.N.C. Louzada \& F.Z. Vaz-De-Mello. 2006. Organization of dung beetle communities (Coleóptera, Scarabaeidae) in areas of vegetation re-establishment in Feira de Santana, Bahia, Brazil. Sitientibus Série Ciências Biológicas 6: 261-266.

MAGURRAN, A.E. 1988. Ecological Diversity and Its Measurement. New Jersey, Princeton, 179p.

Medri, I.M. \& J. Lopes. 2001a. Scarabaeidae (Coleoptera) do Parque Estadual Mata dos Godoy e de área de pastagem, no norte do Paraná, Brasil. Revista Brasileira de Zoologia 18 (Supl. 1): 135-141.

MEdRI, I.M. \& J. LoPes. 2001b. Coleopterofauna em floresta e pastagem no norte do Paraná, Brasil, coletada com armadilha de solo. Revista Brasileira de Zoologia 18 (Supl. 1): 125-133.

MendonçA, F.A. 2000. A tipologia climática: Gênese, características e tendencies, p. 21-62. In: N.M.F. Stipp (Ed.). Macrozoneamento ambiental da Bacia Hidrográfica do Rio Tibagi (PR). Londrina, EDUEL, 196p.

Myers, N.; R.A. Mittermeier C.G. Mittermeier G.A.B. Fonseca \& J. KeNT. 2000. Biodiversity hotspot for conservation priorities. Nature 403: 853-845.

Morelli, E.; P. González-Vainer \& C. Cansiani. 1996. Nidificación, Ciclo de Vida y Estadios Preimaginales de Sulcophanaeus menelas (Laporte, 1840) (Coleoptera: Scarabaeidae). Elytron 10: $135-141$.

Nichols, E.; S. Spector \& J. Louzada. 2008. Ecological functions and ecosystem services provided by Scarabaeinae dung beetles. Biological Conservation 141: 1461-1474.

Ranta, P.; T. Blom; J. Niemelä; E. Joensuu; M. Siitonen. 1998. The fragmented Atlantic rain forest of Brazil: size, shape and distribution of forest fragments. Biodiversity and Conservation 7 : 385-403.

Ronqui, D.C. \& J. Lopes. 2006. Composição e diversidade de Scarabaeoidea (Coleoptera) atraídos pór armadilha de luz em área rural no norte do Paraná, Brasil. Iheringia, Série Zoologia, 96: 103-108.

SAKAI, S. \& T. InOUE. 1999. A new pollination system: dung-beetle pollination discovered in Orchidantha inouei (Lowiacea, Singiberales) in Sarawak, Malaysia. American Journal of Botany 86: 56-61.

Scheffler, P.Y. 2005. Dung beetle (Coleoptera: Scarabaeidae) diversity and community structure across three disturbance regimes in eastern Amazonia. Journal of Tropical Ecology 21: 9-19.

Schiffler, G.; F.Z. Vaz-De-Mello \& C.O. Azevedo. 2003. Scarabaeidae s. str. (Coleoptera) do Delta do Rio Doce e Vale do Suruaca no Município de Linhares, Estado do Espírito Santo, Brasil. Revista Brasileira de Zoociências 5: 205-211.

Silva, F.A.B.; M.I.M. Hernández; S. Ide \& R.C. De Moura. 2007b. Comunidade de escarabeíneos (Coleoptera: Scarabaeidae) copro-necrófagos da região de Brejo Novo, Caruaru, Pernambuco, Brasil. Revista Brasileira de Entomologia 51: 228-233. 
Silva, P. G.; M.A.R. Garcia; L.D. Audino; J.M. Nogueira; L.P. Moraes; A.H.B. Ramos; M.B. Vidal \& M.F.S. Borba. 2007a. Besouros rola-bosta: insetos benéficos das pastagens. Revista Brasileira de Agroecologia 2: 1428-1432.

Silva, P.G.; M.A.R. Garcia \& M.B. Vidal. 2008. Besouros copronecrófagos (Coleoptera: Scarabaeidae stricto sensu) coletados em ecótono natural de campo e mata em Bagé, RS. Ciência e Natura 30: 71-91.

SoARES, F.S. \& M.E. MEDRI. 2002. Alguns aspectos da colonização da bacia do rio Tibagi, p.69-79. In: M.E. Medri; E. BiAnChini; O.A. Shibatta \& J.A. Pimenta (Eds). A bacia do rio Tibagi. Londrina, Edition of the Editors, 595p.

Spector, S. 2006. Scarabaeine dung beetles (Coleoptera: Scarabaeidae: Scarabaeinae): an invertebrate focal taxon for biodiversity research and conservation. The Coleopterists Bulletin 60: 71-83.
Statsoft, Inc. STATISTICA (data analysis software system). Version 6, 2001. Available online at: http://www.statsoft.com [Accessed: 22.V.2009].

Turner, I.M. \& R.T. Corlett. 1966. The conservation value of small, isolated fragments of lowland tropical rain forest. Tree 11: 330-333.

VAZ-DE-Mello, F.Z. 1999. Scarabaeidae s. str. (Coleoptera: Scarabaeoidea) de um Fragmento de Floresta Amazônica no Estado do Acre, Brasil. 1. Taxocenose. Anais da Sociedade Entomológica do Brasil 28: 447-453.

Viana, V.M. \& L.A.F.V. Pinheir. 1988. Conservação da Biodiversidade em Fragmetnos Florestais. Série Técnica IPEF 32: 25-42.

VULINEC, K. 2002. Dung beetle communities and seed dispersal in primary forest and disturbed land in Amazônia. Biotropica 34: 297-309.

Submitted: 07.IV.2010; Accepted: 25.IX.2010.

Editorial responsibility: Pedro Gnaspini 